\title{
Easy Transformation of Escherichia coli: Nanoparticle-Mediated Transformation
}

\author{
Michael R. Green and Joseph Sambrook
}

In this protocol, a colloidal solution containing mineral nanofibers is mixed with Escherichia coli and plasmid DNA and plated immediately on the appropriate selective plates. Sliding frictional forces, created when the bacteria are spread with a polystyrene stir stick across the surface of the agar, may result in penetration of the bacteria by the mineral fibers with its adherent cargo of DNA. The number of transformants increases during the first $60 \mathrm{sec}$ of exposure to the mineral fiber:DNA complex and then reaches a plateau of $\sim 1 \times 10^{6}$ to $2 \times 10^{6}$ transformants/milligrams of DNA. Although not highly efficient, the method is very simple.

It is essential that you consult the appropriate Material Safety Data Sheets and your institution's Environmental Health and Safety Office for proper handling of equipment and hazardous materials used in this protocol.

RECIPES: Please see the end of this protocol for recipes indicated by $<R>$. Additional recipes can be found online at http://cshprotocols.cshlp.org/site/recipes.

E. coli culture (e.g., TOP10 cells or another robust strain) in log phase

HEPES (1 M, pH 7.4)

$\mathrm{KCl}(1 \mathrm{M})$

Plasmid DNA

A standard preparation of a plasmid DNA should be stored in aliquots and used to measure the competence of batches of chemically treated E. coli. pUC19, which is commonly used for this purpose, is available from New England Biolabs.

Sepiolite

Spanish sepiolite with a mean fiber length of $2 \mathrm{~mm}$ and a mean diameter of $20 \mathrm{~nm}$ is available from Kremer Pigmente GmbH \& Co, KG, Germany (catalog no. 58945)

SOB, SOC, or LB agar plates (1\%-2\%) containing the appropriate antibiotic

LB (Luria-Bertani) liquid medium $<\mathrm{R}>$

SOB medium $<\mathrm{R}>$

SOC medium $<\mathrm{R}>$

Equipment

Incubator $\left(37^{\circ} \mathrm{C}\right)$

Polystyrene stick (available from Sarstedt, Germany)

From the Molecular Cloning collection, edited by Michael R. Green and Joseph Sambrook.

(c) 2019 Cold Spring Harbor Laboratory Press

Cite this protocol as Cold Spring Harb Protoc; doi:10.1101/pdb.prot101204 


\section{BOX 1. ESSENTIAL CONTROLS FOR BACTERIAL TRANSFORMATION}

In every experiment, it is essential to include positive controls to measure the efficiency of transformation, and negative controls to eliminate the possibility of contamination and to identify the potential causes of failure.

\section{Negative Controls}

An aliquot of competent cells to which no DNA is added should be carried through the transformation experiment. The entire aliquot should be plated on a single agar plate containing the appropriate antibiotic used to select transformants. No bacterial colonies should grow on this plate or on a selective plate that received no bacteria at all. If any are detected, the following possibilities should be considered.

- The competent cells are contaminated with an antibiotic-resistant strain of bacteria during the experiment. Perhaps one of the solutions/reagents used in the transformation protocol is contaminated.

- The selective plates are defective. Perhaps the antibiotic was omitted altogether from the plates or was added to agar that was too hot.

- The selective plates are contaminated with an antibiotic-resistant strain of bacteria. In this case, colonies usually appear both on the surface of the medium and in the agar.

\section{Positive Controls}

An aliquot of competent cells should be transformed with a known amount of a standard preparation of circular superhelical plasmid DNA. This control provides a measure of the efficiency of transformation and allows a standard for comparison with previous transformation experiments.

\section{METHOD}

See Box 1 for descriptions of essential controls.

1. Autoclave a suspension of $0.01 \%$ sepiolite in $200 \mathrm{~mm} \mathrm{KCl}$ and $5 \mathrm{~mm}$ HEPES (pH 7.4).

2. Briefly centrifuge $500 \mathrm{~mL}$ of a log-phase culture of E. coli.

3. Resuspend the bacterial pellet in $100 \mathrm{~mL}$ of sepiolite suspension, and add $50 \mathrm{ng}$ of plasmid DNA. Wait for $60 \mathrm{sec}$ and then use a polystyrene stick to spread the resulting suspension on a 1\%-2\% agar plate (at least $2 \mathrm{~d}$ old) containing the appropriate antibiotic. Spreading should be continued for $\sim 30 \mathrm{sec}$ after the liquid has soaked into the agar, when the frictional resistance to spreading increases.

4. Incubate the plate overnight at $37^{\circ} \mathrm{C}$.

\section{DISCUSSION}

Yoshida's group in Miyazaki published a series of papers confirming and extending the observation by Appel et al. (1988) that transformation of E. coli by plasmids can be accomplished using mineral nanofibers (Yoshida et al. 2001, 2002, 2007; Yoshida and Sato 2009 [and references therein]). Previously, an impediment to the wider adoption of this method was the nature of the mineral fibers used as the transfection agents: Both Appel et al. (1988) and Yoshida's group used chrysotile, a form of asbestos. More recently, however, Yoshida's observations were confirmed (Wilharm et al. 2010) using a suspension of noncarcinogenic fibers (Spanish sepiolite) instead of the potentially dangerous chrysotile whisker used by Yoshida and his coworkers. The basic protocol outlined by Wilharm et al. (2010) is above. 


\section{LB (Luria-Bertani) Liquid Medium}

\begin{tabular}{lr} 
Reagent & Amount to add \\
\hline $\mathrm{H}_{2} \mathrm{O}$ & $950 \mathrm{~mL}$ \\
Tryptone & $10 \mathrm{~g}$ \\
$\mathrm{NaCl}$ & $10 \mathrm{~g}$ \\
Yeast extract & $5 \mathrm{~g}$
\end{tabular}

Combine the reagents and shake until the solutes have dissolved. Adjust the $\mathrm{pH}$ to 7.0 with $5 \mathrm{~N} \mathrm{NaOH}(\sim 0.2 \mathrm{~mL})$. Adjust the final volume of the solution to $1 \mathrm{~L}$ with $\mathrm{H}_{2} \mathrm{O}$. Sterilize by autoclaving for $20 \mathrm{~min}$ at $15 \mathrm{psi}\left(1.05 \mathrm{~kg} / \mathrm{cm}^{2}\right)$ on liquid cycle.

For solid medium, see the recipe entitled "Media containing agar or agarose." $<\mathrm{R}>$

\section{Media Containing Agar or Agarose}

Prepare liquid media according to the recipe given. Just before autoclaving, add one of the following:

Bacto agar (for plates)

$15 \mathrm{~g} / \mathrm{L}$

Bacto agar (for top agar) $7 \mathrm{~g} / \mathrm{L}$

Agarose (for plates) $15 \mathrm{~g} / \mathrm{L}$

Agarose (for top agarose) $7 \mathrm{~g} / \mathrm{L}$

Sterilize by autoclaving for $20 \mathrm{~min}$ at $15 \mathrm{psi}\left(1.05 \mathrm{~kg} / \mathrm{cm}^{2}\right)$ on liquid cycle. When the medium is removed from the autoclave, swirl it gently to distribute the melted agar or agarose evenly throughout the solution. Be careful! The fluid may be superheated and may boil over when swirled. Before adding thermolabile substances (e.g., antibiotics), allow the medium to cool to $50^{\circ} \mathrm{C}-60^{\circ} \mathrm{C}$, and mix the medium by swirling to avoid producing air bubbles.

Before pouring the plates, set up a color code (e.g., two red stripes for LB-ampicillin plates; one black stripe for LB plates, etc.), and mark the edges of the plates with the appropriate colored markers. Pour plates directly from the flask; allow $\sim 30-35 \mathrm{~mL}$ of medium per $90-\mathrm{mm}$ plate. To remove bubbles from the medium in the plate, flame the surface of the medium with a Bunsen burner before the agar or agarose hardens. When the medium has hardened completely, invert the plates and store them at $4^{\circ} \mathrm{C}$ until needed.

The plates should be removed from storage $1-2 \mathrm{~h}$ before they are used. If the plates are fresh, they will "sweat" when incubated at $37^{\circ} \mathrm{C}$. When this condensation drops on the agar/agarose surface, it allows bacterial colonies or bacteriophage plaques to spread and increases the chances of cross-contamination. This problem can be avoided by wiping off the condensation from the lids of the plates and then incubating the plates for several hours at $37^{\circ} \mathrm{C}$ in an inverted position before they are used. Alternatively, remove the liquid by shaking the lid with a single, quick motion. To minimize the possibility of contamination, hold the open plate in an inverted position while removing the liquid from the lid.

\section{SOB Medium}

Per liter: To $950 \mathrm{~mL}$ of deionized $\mathrm{H}_{2} \mathrm{O}$, add:

Tryptone

Yeast extract $\quad 5 \mathrm{~g}$

$\begin{array}{lr}\mathrm{NaCl} & 0.5 \mathrm{~g}\end{array}$ 
Shake until the solutes have dissolved. Add $10 \mathrm{~mL}$ of a $250 \mathrm{~mm}$ solution of $\mathrm{KCl}$. (This solution is made by dissolving $1.86 \mathrm{~g}$ of $\mathrm{KCl}$ in $100 \mathrm{~mL}$ of deionized $\mathrm{H}_{2} \mathrm{O}$.) Adjust the $\mathrm{pH}$ of the medium to 7.0 with $5 \mathrm{~N} \mathrm{NaOH}(\sim 0.2 \mathrm{~mL})$. Adjust the volume of the solution to $1 \mathrm{~L}$ with deionized $\mathrm{H}_{2} \mathrm{O}$. Sterilize by autoclaving for $20 \mathrm{~min}$ at $15 \mathrm{psi}\left(1.05 \mathrm{~kg} / \mathrm{cm}^{2}\right)$ on liquid cycle. Just before use, add $5 \mathrm{~mL}$ of a sterile solution of $2 \mathrm{M} \mathrm{MgCl}_{2}$. (This solution is made by dissolving $19 \mathrm{~g}$ of $\mathrm{MgCl}_{2}$ in $90 \mathrm{~mL}$ of deionized $\mathrm{H}_{2} \mathrm{O}$. Adjust the volume of the solution to $100 \mathrm{~mL}$ with deionized $\mathrm{H}_{2} \mathrm{O}$ and sterilize by autoclaving for $20 \mathrm{~min}$ at $15 \mathrm{psi}$ $\left[1.05 \mathrm{~kg} / \mathrm{cm}^{2}\right]$ on liquid cycle.)

For solid medium, please see the recipe entitled "Media containing agar or agarose." $<\mathrm{R}>$

\section{SOC Medium}

Per liter: To $950 \mathrm{~mL}$ of deionized $\mathrm{H}_{2} \mathrm{O}$, add:

Tryptone

SOC medium is identical to SOB medium, except that it contains $20 \mathrm{~mm}$ glucose. To prepare $\mathrm{SOB}$ medium, combine the above ingredients and shake until the solutes have dissolved. Add $10 \mathrm{~mL}$ of a $250 \mathrm{~mm}$ solution of $\mathrm{KCl}$. (This solution is made by dissolving $1.86 \mathrm{~g}$ of $\mathrm{KCl}$ in $100 \mathrm{~mL}$ of deionized $\mathrm{H}_{2} \mathrm{O}$.) Adjust the $\mathrm{pH}$ of the medium to 7.0 with $5 \mathrm{~N}$ $\mathrm{NaOH}(\sim 0.2 \mathrm{~mL})$. Adjust the volume of the solution to $1 \mathrm{~L}$ with deionized $\mathrm{H}_{2} \mathrm{O}$. Sterilize by autoclaving for $20 \mathrm{~min}$ at $15 \mathrm{psi}\left(1.05 \mathrm{~kg} / \mathrm{cm}^{2}\right)$ on liquid cycle. Just before use, add

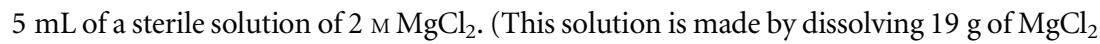
in $90 \mathrm{~mL}$ of deionized $\mathrm{H}_{2} \mathrm{O}$. Adjust the volume of the solution to $100 \mathrm{~mL}$ with deionized $\mathrm{H}_{2} \mathrm{O}$ and sterilize by autoclaving for $20 \mathrm{~min}$ at $15 \mathrm{psi}\left[1.05 \mathrm{~kg} / \mathrm{cm}^{2}\right]$ on liquid cycle.)

After the SOB medium has been autoclaved, allow it to cool to $60^{\circ} \mathrm{C}$ or less. Add $20 \mathrm{~mL}$ of a sterile $1 \mathrm{~m}$ solution of glucose. (This solution is made by dissolving $18 \mathrm{~g}$ of glucose in $90 \mathrm{~mL}$ of deionized $\mathrm{H}_{2} \mathrm{O}$. After the sugar has dissolved, adjust the volume of the solution to $100 \mathrm{~mL}$ with deionized $\mathrm{H}_{2} \mathrm{O}$ and sterilize by passing it through a $0.22-\mu \mathrm{m}$ filter.)

\section{REFERENCES}

Appel JD, Fasy TM, Kohtz DS, Kohtz JD, Johnson EM. 1988. Asbestos fibers mediate transformation of monkey cells by exogenous plasmid DNA. Proc Natl Acad Sci 85: 7670-7674.

Wilharm G, Lepka D, Faber F, Hofmann J, Kerrinnes T, Skiebe E. 2010. A simple and rapid method of bacterial transformation. J Microbiol Methods 80: 215-216.

Yoshida N, Sato M. 2009. Plasmid uptake by bacteria: A comparison of methods and efficiencies. Appl Microbiol Biotechnol 83: 791-798.

Yoshida N, Ikeda T, Yoshida T, Sengoku T, Ogawa K. 2001. Chrysotile asbestos fibers mediate transformation of Escherichia coli by exogenous plasmid DNA. FEMS Microbiol Lett 195: 133-137.
Yoshida N, Kodama K, Nakata K, Yamashita M, Miwa T. 2002. Escherichia coli cells penetrated by chrysotile fibers are transformed to antibiotic resistance by incorporation of exogenous plasmid DNA. Appl Microbiol Biotechnol 60: 461-468.

Yoshida N, Nakajima-Kambe T, Matsuki K, Shigeno T. 2007. Novel plasmid transformation method mediated by chrysotile, sliding friction, and elastic body exposure. Anal Chem Insights 2: 9-15. 


\section{Easy Transformation of Escherichia coli: Nanoparticle-Mediated Transformation}

Michael R. Green and Joseph Sambrook

Cold Spring Harb Protoc; doi: 10.1101/pdb.prot101204

\begin{tabular}{rc}
$\begin{array}{r}\text { Email Alerting } \\
\text { Service }\end{array}$ & Receive free email alerts when new articles cite this article - click here. \\
\hline $\begin{array}{c}\text { Subject } \\
\text { Categories }\end{array}$ & Browse articles on similar topics from Cold Spring Harbor Protocols. \\
& Bacteria (64 articles) \\
& DNA Delivery/Gene Transfer (344 articles) \\
& DNA Delivery/Gene Transfer, general (341 articles) \\
& Microbiology (25 articles) \\
& Molecular Biology, general (1293 articles) \\
& Non-Viral Methods (226 articles) \\
& Plasmids (154 articles) \\
& Vectors (141 articles) \\
\hline
\end{tabular}

